\title{
Pulmo-renální syndrom
}

\author{
Zdenka Hrušková, Vladimír Tesař \\ Klinika nefrologie 1. LF UK a VFN v Praze
}

Pulmo-renální syndrom je definován jako současný výskyt plicního (krvácení do plic) a renálního postižení (s typickým nálezem sprkovité nekrotizujíć rychle progredující glomerulonefritidy). Jeho př́čcinou jsou autoimunitní onemocnění, nejčastěji ANCA-asociované vaskulitidy a anti-GBM (glomerulární bazální membrána) choroba. Pro příznivou prognózu pacientů je zásadní včasné stanovení správné diagnózy a neprodlené zahájení terapie. Terapií volby jsou dodnes zejména vysokodávkované kortikosteroidy a cyklofosfamid, obvykle spolu se současným provedením plazmaferéz. Mezi novější léčebné alternativy patří především rituximab, i když zkušenosti s jeho využitím u nejtěžších případů pulmo-renálního syndromu jsou relativně omezené. Klíčová slova: ANCA, difuzní alveolární hemoragie, protilátky proti glomerulární bazální membráně (anti-GBM), rituximab, rychle progredující glomerulonefritidy, vaskulitida.

\section{Pulmonary-renal syndrome}

Pulmonary syndrome is defined by occurrence of lung involvement (alveolar haemorrhage) in association with renal failure (with a typical crescentic necrotizing rapidly progressive glomerulonephritis). It is caused by an autoimmune disease, most frequently ANCA-associated vasculitides and anti-GBM (glomerular basement membrane) disease. Early establishment of the right diagnosis and immediate treatment are crucial for favourable prognosis of the patients. First choice therapy includes high-dose corticosteroids and cyclophosphamide, usually with plasma exchange added. Newer therapeutic possibilities include especially rituximab even though there is limited experience with its use in the settings of the most severe cases of pulmonary syndrome.

Key words: ANCA, anti-glomerular basement membrane (anti-GBM) antibodies, diffuse alveolar haemorrhage, rapidly progressive glomerulonephritis, rituximab, vasculitis.

\section{Úvod - definice}

Pulmo-renální syndrom (PRS) je charakterizován současným výskytem renálního a respiračního selhání, resp. rychle progredující glomerulonefritidy a difuzního alveolárního krvácení, vzniklých na podkladě autoimunitního onemocnění (1, 2). Nejčastější príčinou PRS jsou ANCA (Anti-Neutrophil Cytoplasmic Antibodies) - asociované vaskulitidy (AAV) zodpovědné za približně 55-75\% všech prípadů PRS a anti-GBM (glomerulární bazální membrána) choroba (dřive Goodpastureova, asi 10-15\%). Méně častou príčinou vzniku PRS jsou pak další autoimunitní onemocnění (Tab. 1), která ke krvácení do plic a/nebo selhání ledvin vedou poměrně vzácně, i když jejich celkový výskyt vzácný být nemusí (1-4).

Patologickým podkladem PRS je zánět (vaskulitida) malých cév (arteriol, kapilár, venul) spojený s nekrózou a narušením cévní stěny. V plicích pak dochází k prímé extravazaci erytrocytů do alveolů (difuzní alveolární hemo- ragii - DAH). V ledvinách je PRS doprovázen průnikem buněk imunitního systému a fibrinu porušenou glomerulární bariérou do močového prostoru, s následnou tvorbou charakteristických srpků a vznikem nekrotizujićí rychle progredujicí glomerulonefritidy (RPGN), která může vést k rychlému selhání ledvin (řádově během několika dní až týdnů) $(1,3,5,6)$. RPGN jsou obvykle děleny do 3 skupin podle prítomnosti a distribuce imunodepozit v imunofluorescenčním obraze v renální biopsii:

- typ 1 (10\%) - s lineárními depozity lgG podél glomerulární bazální membrány (GBM), vyskytující se u anti-GBM choroby,

- typ 2 (10-15\%) - s granulárními depozity imunoglobulinů a komplementu, který může být projevem různých imunokomplexových onemocnění (např. systémového lupus erythematodes),

- typ 3 (75-80\%) - s tzv. pauciimunitním obrazem v imunofluorescenci s malým množstvím nebo zcela chybějícími imunodepozity, který je charakteristický pro ANCA-asociované vaskulitidy (AAV) (3-5). 


\section{Výskyt onemocnění}

Výskyt pulmo-renálního syndromu je obecně vzácný, ANCA-asociované vaskulitidy mají v Evropě odhadovanou incidenci kolem 10-20/milion obyvatel/rok a anti-GBM choroba jen 1-1,5/milion obyvatel/ rok, navíc ne všechny prípady těchto onemocnění se projeví právě pulmo-renálním syndromem (u AAV se DAH vyskytuje u 10-35 \% pacientů a postižení ledvin u více než 70-80\%, u anti-GBM choroby je výskyt DAH popisován u 60-80 \% pacientů a postižení ledvin u príbližně 90 \%) (1).

AAV se nejčastěji vyskytují u pacientů v 5.-7. dekádě života, s téměř stejným zastoupením žen a mužů, anti-GBM má vrchol výskytu u mladých mužů ve 2.-3. dekádě a druhý (menší) pak v 6.-7. dekádě. Imunokomplexové vaskulitidy (zejména IgA vaskulitida a lupusová vaskulitida) jsou častější u mladších pacientů.

Jak u AAV, tak u anti-GBM choroby byla popsána genetická predispozice, která ke vzniku onemocnění prisspívá spolu s environmentálními faktory. Onemocnění může být spuštěno proběhlou infekcí, vznik krvácení do plic u anti-GBM choroby je častější u kuřáků, u AAV je výskyt častější u pacientů s vyšší expozicí křemíku, nebo také u farmářu $(1,2,7)$.

Přestože jsou onemocnění vzácná, jedná se o onemocnění potenciálně život ohrožující, na která je vhodné pomýšlet ve všech nejasných prípadech současného (závažného) akutního postižení ledvin a plic. Mnoho studií prokázalo, že prognóza pacienta je jednoznačně závislá na včasném stanovení diagnózy a neodkladném zahájení přislušné terapie.

\section{Diagnostický postup při podezření na pulmo-renální syndrom}

Klinický obraz i časový průběh PRS je značně variabilní, od velmi mírných či jen plíživě nastupujících projevů téměř bez subjektivních potíží, po velmi závažný stav progredující během několika hodin k nutnosti umělé plicní ventilace a/nebo dialýzy. Přiznaky a projevy jak DAH (dušnost, hemoptýza, anémie, hypoxie), tak RPGN (oligurie, periferní nebo plicní edém, hypertenze) nejsou ani specifické, ani př́liš senzitivní. Někdy bývají přitomny systémové („chřipkovité”) prríznaky (např. artralgie, teploty, únava, úbytek váhy) a patrny mohou být projevy systémové vaskulitidy v jiných postižených orgánech (typicky zejména v ORL oblasti) $(1,2,8)$.

$\checkmark$ př́padě již jen důvodného klinického podezření na PRS je indikováno imunologické vyšetření - stanovení ANCA protilátek (protilátek proti cytoplazmě neutrofilů) a protilátek proti glomerulární bazální membráně (anti-GBM). Pozitivní výsledek je pro stanovení diagnózy ve správném klinickém kontextu považován za dostatečný, diagnózu Ize ještě potvrdit provedením (nejčastěji renální) biopsie, ale ta nemusí být v akutní fázi snadná a neměla by v žádném prípadě zpozdit príslušnou terapii. Pokud jsou ANCA a anti-GBM protilátky negativní, stává se renální biopsie naléhavější, vhodné je vyšetřit hladiny komplementu (C3, C4), hladinu IgA, anti-nukleární protilátky, protilátky proti dvouvláknové DNA (anti-dsDNA), revmatoidní faktor, ASLO a prípadně kryoglobuliny $(1,4,9)$.

Ze zobrazovacích metod je základní diagnostickou metodou pro plicní postižení prostý RTG snímek hrudníku, pokud je ale dostupné, mělo by být u pacientů s podežrením na pulmo-renální syndrom preferováno HRCT vyšetření. Zejména v prípadech diagnostických pochyb či obav z infekce je na místě bronchoskopie s bronchoalveolární laváží. Plicní biopsie může definitivně potvrdit diagnózu
Tab. 1. Příčiny pulmo-renálního syndromu (upraveno podle (1, 2))

\begin{tabular}{|c|c|}
\hline \multicolumn{2}{|l|}{ Příčiny pulmo-renálního syndromu } \\
\hline ANCA-asociované vaskulitidy: & $\begin{array}{l}\text { Granulomatóza s polyangiitidou } \\
\text { (GPA, dříve Wegenerova) } \\
\text { Mikroskopická polyangiitida } \\
\text { (MPA) } \\
\text { Eozinofilní granulomatóza } \\
\text { s polyangiitidou (EGPA, dříve } \\
\text { syndrom Churga a Straussové) }\end{array}$ \\
\hline \multicolumn{2}{|c|}{ Anti-GBM choroba (Goodpastureova) } \\
\hline Jiné primární vaskulitidy: & $\begin{array}{l}\text { IgA vaskulitida (Henoch- } \\
\text { Schoenleinova purpura) } \\
\text { Kryoglobulinemická vaskulitida } \\
\text { Behcetova choroba }\end{array}$ \\
\hline \multicolumn{2}{|l|}{ Antifosfolipidový syndrom } \\
\hline Systémová onemocnění pojiva & $\begin{array}{l}\text { Systémový lupus } \\
\text { erythematodes } \\
\text { Revmatoidní artritida } \\
\text { (vaskulitida) } \\
\text { Systémová sklerodermie } \\
\text { Polymyositida/ } \\
\text { dermatomyositida } \\
\text { Smíšené onemocnění pojiva }\end{array}$ \\
\hline Polékové vaskulitidy & $\begin{array}{l}\text { Hydralazin } \\
\text { Propyl-thiouracil } \\
\text { Penicilamin }\end{array}$ \\
\hline Idiopatický PRS & \\
\hline
\end{tabular}

Tab. 2. Redukce dávek pulzního cyklofosfamidu s ohledem na věk a renálni funkci (podle studie CYCLOPS (15))

\begin{tabular}{|l|c|c|}
\hline \multirow{2}{*}{ Věk (v letech) } & \multicolumn{2}{|c|}{ Kreatinin $(\boldsymbol{\mu m o l} / \mathbf{l})$} \\
\cline { 2 - 3 } & $\mathbf{3 0 0}$ & $\mathbf{3 0 0}$ \\
\hline$<60$ & $15 \mathrm{mg} / \mathrm{kg} / \mathrm{pulz}$ & $12,5 \mathrm{mg} / \mathrm{kg} / \mathrm{pulz}$ \\
\hline $60-70$ & $12,5 \mathrm{mg} / \mathrm{kg} / \mathrm{pulz}$ & $10 \mathrm{mg} / \mathrm{kg} / \mathrm{pulz}$ \\
\hline$>70$ & $10 \mathrm{mg} / \mathrm{kg} / \mathrm{pulz}$ & $7,5 \mathrm{mg} / \mathrm{kg} / \mathrm{pulz}$ \\
\hline
\end{tabular}

vaskulitidy, ale výtěžnost transbronchiální biopsie nebývá vždy vysoká a ostatní způsoby odběru plicní biopsie jsou již poměrně dost zatěžující. V zahraniční literatuře bývá také zmiňováno funkční vyšetření plic s typickým nálezem zvýšené difuzní kapacity pro CO (DLCO) při pokračujícím krvácení (10), ale i jeho praktický diagnostický význam je v akutních stavech sporný.

Co se týče postižení ledvin, kromě zvýšeného (stoupajícího) kreatininu je pro diagnózu zásadní vyšetření moče, kde u pacienta s aktivní proliferativní glomerulonefritidou nacházíme smíšený močový nález: mikroskopickou hematurii (glomerulární, tedy s dysmorfními erytrocyty a/nebo akantocyty) a malou až střední proteinurií. Renální biopsie je pak u RPGN diagnostickou metodou volby a doporučuje se ji provést nejen pro vlastní potvrzení diagnózy, ale i pro posouzení míry aktivního/ chronického postižení a reverzibility změn, jak již ale bylo zmíněno, není pro zahájení terapie zcela nezbytná (4).

Diferenciálně-diagnosticky je při podezření na PRS třeba vyloučit jiná onemocnění, která mohou současně postihovat plíce a ledviny a napodobovat jej, jako je např. kardiální insuficience s plicním edémem a hypoperfuzí ledvin, maligní hypertenze, infekční onemocnění (např. legionella, leptospiróza, malárie) či bronchopneumonie se sepsí-indukovaným renálním selháním. V zásadě každá příčina akutního renálního selhání může vést k oligurii s následným plicním edémem, který je také nutné odlišit od DAH. Situace mưže být navíc 
Obr. 1. Diagnostický algoritmus při podezření na pulmo-renální syndrom (upraveno podle (1))

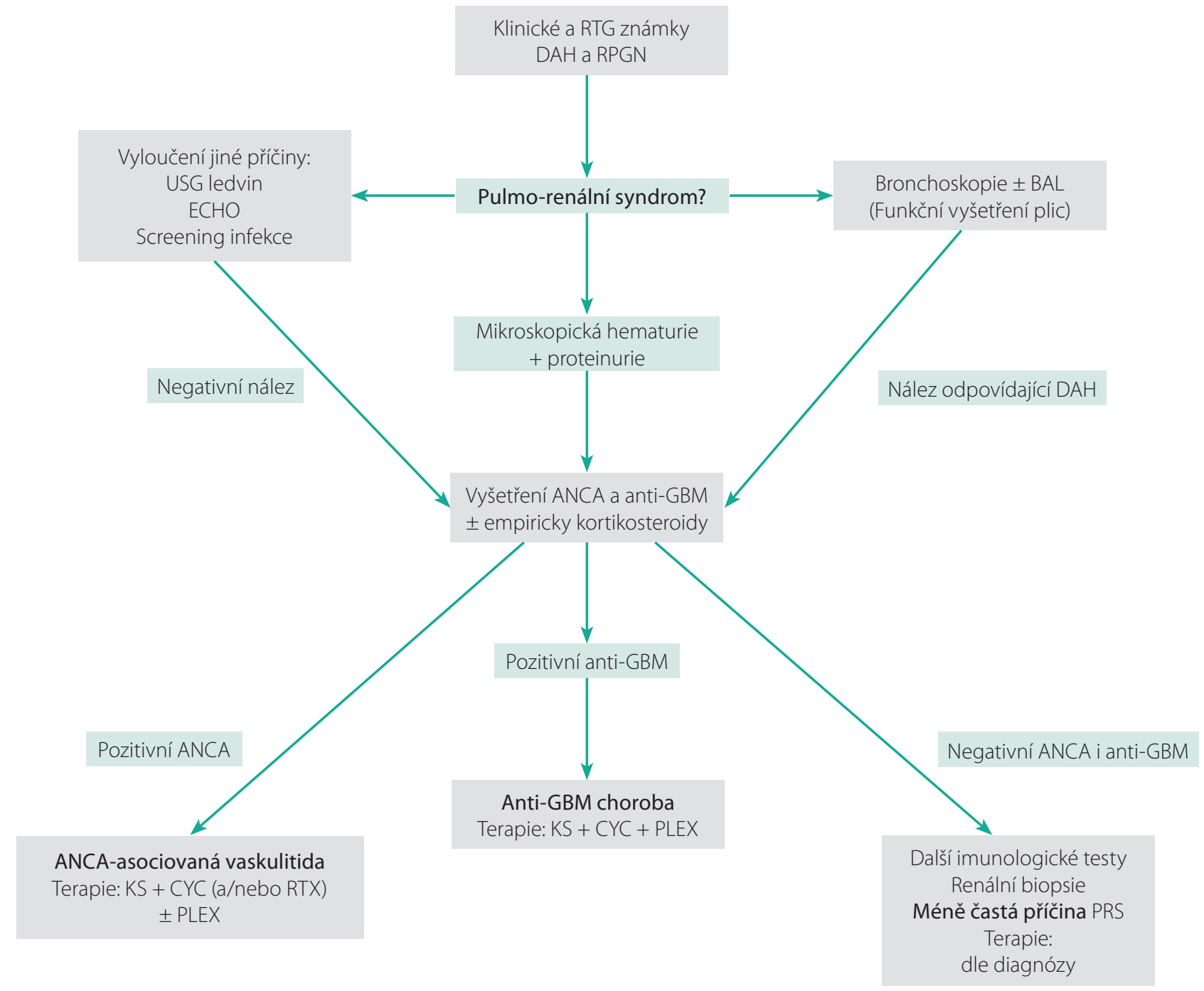

někdy komplikována současným výskytem DAH a infekce, či DAH v terénu plicního edému (1, 2). Možný diagnostický algoritmus při PRS je znázorněn na Obr. 1.

\section{Terapie}

Jak již bylo zmíněno, pulmo-renální syndrom může být akutně život ohrožujícím stavem a jakékoli prodlení v léčbě je spjato se zhoršením prognózy. Obecně mají nejvyšší mortalitu a riziko ireverzibilního renálního selhání pacienti s nejpokročilejší renální insuficiencí, zejména ti s nutností dialýzy již v době diagnózy, dále starší pacienti a také pacienti s DAH vyžadujícím mechanickou ventilační podporu (3, 8, 10). Terapie pulmo-renálního syndromu by měla být přizpůsobena základní diagnóze, tíži postižení, stavu pacienta a jeho komorbiditám, pravdou však je, že tradiční terapeutický př́stup je společný a zahrnuje vysokodávkované (pulzní) kortikosteroidy, cyklofosfamid a často také plazmaferézy. Kortikosteroidy potlačují zánětlivou reakci, cyklofosfamid zastavuje produkci autoprotilátek a cílem plazmaferézy je obecně rychlé odstranění patogenních cirkulujících autoprotilátek (či jiných patogenních substancí).

$\checkmark$ poslední době byly u pacientů s vaskulitidou testovány i novějši léčebné možnosti, nejvíc zkušeností je doposud k dispozici s rituxima- bem, ale je nutno podotknout, že pacienti s těžkým průběhem byli z randomizovaných studií mnohdy vylučováni.

V následující části budou uvedeny jednotlivé př́činy PRS spolu s přehledem základních terapeutických možností.

\section{ANCA-asociované vaskulitidy (AAV)}

AAV jsou nekrotizující vaskulitidy malých (až středních) cév bez (nebo jen s malým množstvím) imunodepozit, obvykle (i když ne vždy) spojené s výskytem ANCA protilátek. ANCA mohou být u AAV namíreny proti proteináze 3 (PR3-ANCA), pak v imunofluorescenci obvykle vykazují cytoplazmatický typ fluorescence (c-ANCA), nebo je cílovým antigenem myeloperoxidáza (MPO-ANCA) a typ imunofluorescence je perinukleární (p-ANCA).

Mezi AAV řadíme 3 klinicko-patologické jednotky, a to granulomatózu s polyangiitidou (GPA, dríve známou pod názvem Wegenerova granulomatóza) - častěji PR3-ANCA pozitivní; mikroskopickou polyangiitidu (MPA) - častěji MPO-ANCA pozitivní; a eozinofilní granulomatózu s polyangiitidou (EGPA, dř́ve syndrom Churga a Straussové) - častěji MPO-ANCA pozitivní, ale také ANCA negativní (11).

Jak již bylo zmíněno, AAV (zejména GPA a, MPA, jen vzácně EGPA) jsou nejčastější príčinou PRS. Prognóza neléčené systémové AAV bývala 
velmi špatná (roční mortalita činila až 90 \%), ale po zavedení kombinované imunosupresivní terapie do praxe se výrazně zlepšila (s dosažením remise až u 80-90 \% pacientů), i když je mortalita stále zvýšena proti stejně staré běžné populaci a problémem zưstává také vysoké procento konečného stadia renálního selhání (end-stage renal disease - ESRD) s nutností náhrady funkce ledvin. U pacientů se závažným DAH je proti ostatním pacientům s AAV navíc stále vysoké i riziko celkové (časné i pozdní) mortality, v jedné nedávné retrospektivní studii u pacientů se závažným krvácením do plic bylo po 3 měsících naživu 83 \% pacientů a po přibližně 4 letech 59 \% (8).

\section{Současná terapie PRS u AAV}

Terapii AAV Ize obecně rozdělit na léčbu indukční, jejímž cílem je navodit remisi onemocnění, a léčbu udržovací, jejímž cílem je předejít vzniku relapsů onemocnění.

Zlatým standardem v léčbě systémové vaskulitidy byl od 70. let 20. století terapeutický režim s dlouhodobě (minimálně 1 rok) podávaným perorálním cyklofosfamidem a postupně detrahovanou dávkou kortikosteroidů (vstupně $1 \mathrm{mg}$ prednisonu/kg/den). Za posledních 25-30 let pak byla pak zejména díky aktivitám Evropské vaskulitické společnosti (EUVAS) provedena řada studií, které vedly k dnes obecně akceptovanému schématu léčby AAV zmíněnému i v doporučeních pro léčbu AAV $(9,12-14)$.

Ve stručnosti je $v$ indukční léčbě AAV (PRS) indikováno podání vysoké dávky kortikosteroidů (vstupně prednison 1 mg/kg/den), terapie může být v úvodu zahájena podáním 3 pulzů metylprednisolonu à 250 mg až $1 \mathrm{~g}$ po 3 po sobě jdoucí dny. U pacientů s PRS je pak stále nejčastější a nejosvědčenější léčbou cyklofosfamid, který může být podán perorálně (2 mg/kg/den), nebo (dnes častěji) v intravenózních pulzech (15 mg/pulz) à 2-3 týdny, dávku cyklofosfamidu je nutno redukovat s ohledem na věk a renální funkci (Tab. 2), doporučuje se sledovat i hladinu leukocytů a dávku při jejich poklesu také upravit. Intravenózní podání cyklofosfamidu (CYC) je v navození remise stejně účinné jako podání perorální a je spojeno s jeho nižší kumulativn dávkou a nižším výskytem leukopenie (15), a přestože bezpečnost a účinnost intravenózního podání nebyla v původní studii testována u pacientů s renálním selháním, byl tento postup ověřen v menších studiích a může být u pacientů s těžší formou PRS výhodnější (16). Možný častější výskyt relapsů při intravenózním podání byl sice popsán, ale nebyl spjat s vyšším rizikem mortality či morbidity (17) a v akutní fázi léčby PRS není ani rozhodující.

Oproti dávnějšímu postupu je dnes po 3-6 měsících (po dosažení stabilní remise) terapie CYC zpravidla ukončena a pacienti jsou převedeni na udržovací terapii, nejčastěji azathioprinem (AZA) $\checkmark$ dávce $2 \mathrm{mg} / \mathrm{kg} / \mathrm{den}$. Bylo prokázáno, že časné zahájení udržovací terapie nezvyšuje počet relapsů ani nezhoršuje celkové přežití (18) Alternativou azatioprinu v udržovací léčbě (nejčastěji u pacientů se současnou nutností léčby hyperurikemie allopurinolem, který interferuje s metabolizmem azatioprinu) je methotrexát, který by ale neměl být použiván u pacientů s pokročilejší renální insuficiencí, nebo mykofenolát-mofetil, jenž byl ale v randomizované studii v porovnání s azathioprinem inferiorní (19).

\section{Plazmaferézy v léčbě PRS u AAV}

Léčebná výměnná plazmaferéza (PLEX), v nejčastěji používaném režimu 7 výkonů během 14 dnů, aspoň první 2-3 výkony denně, je dle KDIGO guidelines doporučena v léčbě pacientů s AAV s nutností dialýzy nebo rychle rostoucím sérovým kreatininem a navrhována u pacientů s krvácením do plic, tedy v praxi téměř u všech pacientů s PRS (12). Přestože je v této indikaci plazmaferéza hojně využívána, důkazy ze studií tak zcela jednoznačné nejsou a pro pacienty s DAH donedávna data z randomizovaných studií v zásadě neexistovala.

Na základě několika provedených studií s PLEX u AAV, jejichž výsledky byly shrnuty v metaanalýze (20), vedou plazmaferézy u AAV ke snížení rizika závislosti na dialýze v čase 12 měsíců (relativní riziko (RR): 0,64; 95\% konfidenční interval (CI): 0,47-0,88), ale nevedou ke snížení celkové mortality (RR: 1,01; 95\% Cl: 0,71-1,43). V dlouhodobém sledování pacientů léčených plazmaferézou navíc původní príznivý vliv na obnovu renální funkce mizí (21).

Pro získání lepších důkazů v této oblasti byla provedena dosud největší studie u pacientů s AAV nazvaná PEXIVAS (22), která probíhala po celém světě ve více než 100 centrech. Cílem studie bylo porovnat u pacientů s renální insuficiencí s GFR pod $50 \mathrm{ml} / \mathrm{min}$ a/nebo s plicním krvácením účinnost přidání plazmaferéz ke standardní terapii s terapií bez plazmaferézy (studie zároveň mechanizmem dvojité randomizace porovnávala vysokou - standardní - a nízkou dávku kortikosteroidů). Studii se podařilo dokončit, zařazeno do ní bylo přes 700 pacientů, ale výsledky zatím byly publikovány jen formou abstrakt/ústních sdělení (Walsh M et al, ERA-EDTA kongres, Kodaň, 2018 a Merkel P et al, ACR Annual Meeting, Chicago, 2018). Dle předběžného sdělení z kongresů nebyl mezi pacienty léčenými plazmaferézou a pacienty bez plazmaferézy zjištěn žádný významný rozdíl, a to ani u pacientů s krvácením do plic, ale pro větší závěry a revizi stávajících doporučení se domníváme, že je třeba vyčkat definitivních výsledků této studie.

\section{Rituximab v léčbě PRS u AAV}

Rituximab, chimérická monoklonální protilátka proti antigenu CD20, se na základě výsledků 2 randomizovaných studií RAVE (23) a RITUXVAS (24), které shodně prokázaly jeho srovnatelnou účinnost v indukční léčbě AAV v porovnání s cyklofosfamidem (jak perorálním - RAVE, tak pulzním intravenózním - RITUXVAS), stal dnes již běžně využívanou alternativou v indukční léčbě AAV a v řadě center je dnes indikován i jako terapie první volby. Nepochybně je pak možné využít zejména jeho potenciálně vyšší účinnost u (opakovaně) relabujících pacientů, kde by měl být RTX jistě lékem volby.

Kromě indukční léčby je dnes RTX indikován i v léčbě udržovací, kde byla ve francouzské randomizované studii MAINRITSAN (a to i dlouhodobém sledování) prokázána několikanásobně vyšší účinnost opakovaného podávání RTX v udržení remise oproti standardní terapii azathioprinem $(25,26)$.

U pacientů s PRS je ale situace přece jen trochu komplikovanější, nebot pacienti s opravdu těžkým postižením při AAV byli vyloučeni ze všech provedených studií. Ve studii RITUXVAS, ve které byli rituximabem léčeni i pacienti s těžším renálním postižením (medián GFR ve větvi s rituximabem byl $20 \mathrm{ml} / \mathrm{min}, 24 \%$ vyžadovalo dialýzu), byla léčba 
rituximabem doplněna v úvodu o 2 pulzy cyklofosfamidu - z obavy, že nástup účinku RTX může být pomalejší. Ve studii RAVE byl RTX podáván

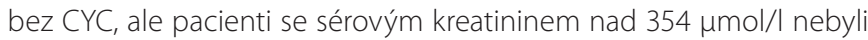
do studie vưbec zařazováni. Účinnost a bezpečnost léčby rituximabem (bez současného podání cyklofosfamidu) u pacientů s těžkou renální vaskulitidou a těžkým postižením obecně tak zatím zůstává diskutabilní, i když v klinické praxi a malých studiích Ize pozorovat tendenci využívat RTX samostatně a nezdá se, že by tímto postupem byli pacienti ohroženi (27). Dle našeho názoru je možné v této indikaci RTX jako první volbu bez CYC využít zejména tam, kde jsou obavy z možných nežádoucích účinků cyklofosfamidu (velmi mladí, nebo naopak staří - fragilní - pacienti, pacienti s rizikem infekčních komplikací apod.).

\section{Kortikosteroidy v léčbě AAV}

Kortikosteroidy (KS) byly donedávna považovány za naprosto nedílnou součást léčby AAV a (přinejmenším) v Evropě byly obvykle podávány v nízkých dávkách dlouhodobě, príčemžrychlost detrakce v úvodu byla relativně pozvolná. Vysoká prètrvávající mortalita s podstatným výskytem infekčních komplikací u pacientů s AAV v prvním roce léčby a srovnatelný výskyt nežádoucích účinků ve větvi s RTX is CYC ve studiích RAVE a RITUXVAS ale vedl k obrácení pozornosti na terapii KS, které se zdály být spoluviníkem těchto pozorování a zároveň oblastí, kde lze léčbu snadno modifikovat.

Jedním ze způsobů, jak Ize dávku KS snižit, a to i u pacientů s těžším postižením, je podat v úvodu RTX spolu s nižší dávkou CYC a KS pak rychle detrahovat či úplně vysadit. Tento způsob byl úspěšně využit v několika menších studiích $(28,29)$. Ve výše zmíněné studii PEXIVAS byla kromě účinnosti PLEX studována i účinnost a bezpečnost léčby nižší dávkou KS (úvodní dávka KS byla stejná, ale detrakce byla v jedné větvi studie výrazně rychlejší, s dosažením přibližně 50 \% kumulativní dávky prednisonu). Jak bylo řečeno, definitivní výsledky zatím nebyly publikovány, ale předběžná data naznačují, že rychlejší snížení dávky KS bylo stejně účinné, a přitom spojené s nižším výskytem nežádoucích účinků, a proto bude zřejmě do budoucna preferováno.

$\checkmark$ dnešní době je u AAV testována i léčba s úplným vynecháním KS, např. ve studii s avacopanem (NCT02994927), inhibitorem C5a receptoru, který by mohl KS v léčebném algoritmu zcela nahradit, ale data jsou jen předběžná, a navíc opět ani zde nebyli zařazováni pacienti s PRS s těžším postižením.

\section{Anti-GBM choroba}

Anti-GBM choroba je podle revidované klasifikace vaskulitid řazena mezi imunokomplexové vaskulitidy malých cév, postihující glomerulární a/nebo plicní kapiláry, s lineární depozicí anti-GBM protilátek podél bazální membrány (11). Plicní postižení způsobuje krvácení do plic a renální postižení nekrotizující srpkovitou GN. Přestože se nejedná o klasické imunokomplexové onemocnění, při chorobě dochází k tvorbě imunokomplexů in situ, skládajících se z protilátek navázaných na bazální membránu glomerulárních nebo plicních kapilár. Anti-GBM protilátky jsou namířeny proti nekolagenní doméně 1 a3 řetězce kolagenu IV. Dnes je pro onemocnění, které se může projevit i izolovaně jen v ledvinách, nebo méně často izolovaně v plicích, preferován název anti-GBM choroba. Goodpastureův syndrom je dřivější označení pro pulmo-renální syndrom (i jiné etiologie - např. při AAV), Goodpastureova choroba je pak název používaný pro pulmo-renální syndrom s pozitivitou anti-GBM $(3,4)$, ale název již není preferován (11).

$U$ anti-GBM choroby je snad ještě více než u AAV nutno zdůraznit potřebu rychlého stanovení diagnózy a okamžitého zahájení terapie. Prognóza onemocnění výrazně závisí na vstupní úrovni renální funkce, pokud je onemocnění diagnostikováno při kreatininu pod približně 500 umol/I, je šance na renální přežití dobrá, pokud je však již pacient dialyzován, prognóza se výrazně zhoršuje.

Podle KDIGO doporučení je u všech pacientů s anti-GBM indikována terapie kortikosteroidy, cyklofosfamidem a plazmaferézou, mimo pacienty bez extrarenálního postižení, závislé na dialýze, se 100 \% srpkư v renální biopsii (12), kde je již naděje na obnovu renální funkce mizivá. Rozhodnutí neléčit pacienta ale musí být pečlivě zváženo, nebot' i pacienti vyžadující dialýzu někdy renální funkci obnoví a existuje riziko pozdního vzniku plicního krvácení (30).

Standardní terapie zahrnuje kortikosteroidy, cyklofosfamid a plazmaferézy (denně po dobu 14 dnů nebo do dosažení negativity anti-GBM protilátek). Terapie kortikosteroidy bývá obvykle zahájena podáním intravenózních pulzů metylprednisolonu po 3 dny. Cyklofosfamid byl dřive podáván zejména perorálně v dávce $2 \mathrm{mg} / \mathrm{kg} / \mathrm{den}$, novější studie ale popisují i možnost intravenózních pulzů cyklofosfamidu, které byly převzaty z léčebných schémat u AAV. Na rozdíl od AAV je u anti-GBM choroby riziko relapsu nízké a udržovací imunosupresivní terapie není indikována. Délka terapie cyklofosfamidem by měla být 2-3 měsíce, kortikosteroidy by měly být vysazeny do 6 měsíců. Pokud jsou však patrny trvající klinické známky aktivity onemocnění nebo trvá pozitivita anti-GBM protilátek, může být terapie prodloužena na 6-9 měsíců a ke snižení kumulativní dávky CYC je možné u pacientů vyžadujících delši dobu imunosuprese později použít i azathioprin (4).

Až kolem $40 \%$ pacientů s anti-GBM má zároveň pozitivní ANCA protilátky (častěji MPO-ANCA). Pacienti s dvojitou pozitivitou ANCA a anti-GBM sdružuji „nevýhody“ obou diagnóz: renální přežití pacientů s dvojitou pozitivitou ANCA a ani-GBM je podobné jako u izolované pozitivity anti-GBM, tedy horší než u AAV, na druhou stranu pacienti na rozdíl od izolované pozitivity anti-GBM podobně jako AAV relabují (31). Indukční terapie by měla být volena podle zásad léčby anti-GBM choroby a udržovací podle zásad léčby AAV.

U anti-GBM choroby existují zkušenosti s léčbou rituximabem, ale jsou jen ve formě kazuistik a nezdá se, že by RTX vedl k vyššímu renálnímu přežití. Zajímavým novým prístupem může být léčba pomocí imunoglobulin-G degradujícího enzymu původem ze Streptococcus pyogenes (IdeS), který by mohl nahradit terapii plazmaferézou a je u antiGBM choroby testován ve studii fáze II (NCT03157037).

\section{Jiné etiologie PRS}

Jedná se o velmi heterogenní skupinu onemocnění (Tab. 1), u nichž je manifestace s klinickým obrazem pulmo-renálního syndromu vzácná. Terapie by opět měla být přizpůsobena základnímu onemocnění a závažnosti jeho průběhu. Pokud je stav závažnější, bývá i v těchto indikacích využívána kombinovaná imunosuprese kortikosteroidy a cyklofosfamidem, někdy i s přidáním plazmaferéz. 


\section{Závĕr - výhled do budoucna}

Prognóza PRS se v posledních desetiletích výrazně zlepšila, ale stále se jedná o stav závažný a potenciálně život ohrožující. Klíčem ke zlepšení prognózy onemocnění je jednoznačně časná diagnostika a časné zahájení príślušné terapie, je tedy třeba na onemocnění pomýšlet. S rozvojem biologické léčby lze očekávat narůstající využití RTX i v léčbě pacientů s AAV se závažnějším postižením, asi se ale v této indikaci nedočkáme randomizované studie. V současném dávkování,

\section{LITERATURA}

1. West SC, Arulkumaran N, Ind PW, et al. Pulmonary-renal syndrome: a life threatening but treatable condition. Postgrad Med J 2013; 89: 274-283.

2. McCabe C, Jones Q, Nikolopoulou A, et al. Pulmonary-renal syndromes: an update for respiratory physicians. Respir Med 2011; 105: 1413-1421.

3. Tesař V, Honsová E, Ryšavá R, et al. Glomerulopatie. In: Tesař V, Viklický O (eds.) Klinická nefrologie. Praha: Grada 2015; 91-164.

4. Hrušková Z, Tesař V. Rychle progredující glomerulonefritidy - novinky v léčbě. Postgra duální medicína 2015: 5: 27-32.

5. Moroni G, Ponticelli C. Rapidly progressive crescentic glomerulonephritis: Early treatment is a must. Autoimmun Rev 2014; 13: 723-729.

6. Greenhall GH, Salama AD. What is new in the management of rapidly progressive glomerulonephritis? Clin Kidney J 2015; 8: 143-150.

7. Xiao H, Hu P, Falk RJ, et al. Overview of the Pathogenesis of ANCA-Associated Vasculitis. Kidney Dis (Basel) 2016; 1: 205-215.

8. Hruskova Z, Casian AL, KonopasekP, et al. Long-term outcome of severe alveolar haemorrhage in ANCA-associated vasculitis: a retrospective cohort study. Scand J Rheumatol 2013;42: 211-214 9. Yates M, Watts RA, Bajema IM, et al. EULAR/ERA-EDTA recommendations for the management of ANCA-associated vasculitis. Ann Rheum Dis 2016; 75: 1583-1594.

10. Casian A, Jayne D. Management of alveolar hemorrhage in lung vasculitides. Semin Respir Crit Care Med 2011; 32: 335-345.

11. Jennette JC, Falk RJ, Bacon PA, et al. 2012 Revised international Chapel Hill Consensus Conference nomenclature of vasculitides. Arthritis \& Rheum 2013; 65: 1-11.

12. Kidney Disease: Improving Global Outcomes (KDIGO) Glomerulonephritis Work Group. KDIGO clinical practice guideline for glomerulonephritis. Kidney Int Suppl 2012; 2: 139-274 13. Ntatsaki $E_{1}$ Carruthers D, Chakravarty $K$, et al. BSR and BHPR quideline for the management of adults with ANCA-associated vasculitis. Rheumatology (Oxford) 2014; 53: 2306-2309 14. Tesar V, Hruskova Z. Conventional induction and maintenance treatment of Antineutrophil cytoplasmic antibodies-associated vasculitis - still of value for our patients? Expert Opin Pharmacother 2015; 16: 1683-1702.

15. De Groot K, Harper L, Jayne DR, et al. Pulse versus daily oral cyclophosphamide for induction of remission in antineutrophil cytoplasmic antibody-associated vasculitis: a randomized trial. Ann Intern Med 2009; 150: 670-680

16. Pepper RJ, Chanouzas D, Tarzi R, et al. Intravenous cyclophosphamide and plasmapheresis in dialysis-dependent ANCA-associated vasculitis. Clin J Am Soc Nephrol 2013; 8: 219-224 17. Harper L, Morgan MD, Walsh M, et al. Pulse versus daily oral cyclophosphamide for induction of remission in ANCA-associated vasculitis: long-term follow-up. Ann Rheum Dis 2012. 71: 955-960. se zohledněním renální funkce, věku a krevního obrazu, se i podání cyklofosfamidu zdá bezpečné a pro pacienty s PRS velmi osvědčené. Stejně tak není chybou podat zejména v úvodu (co nejdřive, i jen při podezření na PRS) vysokou dávku kortikosteroidů, ale ta by měla být po zlepšení stavu rychle snižována. Indikace k provedení plazmaferéz byla diskutována výše a nelze vyloučit, že bude spiše ustupovat. Čas ukáže, zda se do denní léčebné praxe zařadí některé z dalších novějších léků testovaných (zejména) u AAV.

18. Jayne D, Rasmussen N, Andrassy K, et al. European Vasculitis Study Group. A randomized trial of maintenance therapy for vasculitis associated with antineutrophil cytoplasmic autoantibodies. N Engl J Med 2003; 349: 36-44.

19. Hiemstra TF, Walsh M, Mahr A, et al. Mycophenolate mofetil vs azathioprine for remission maintenance in antineutrophil cytoplasmic antibody-associated vasculitis: a randomized controlled trial. JAMA 2010; 304: 2381-2388.

20. Walsh M, Catapano F, Szpirt W, et al. Plasma exchange for renal vasculitis and idiopathic rapidly progressive glomerulonephritis: a meta-analysis. Am J Kidney Dis 2011; 57: 566-574.

21. Walsh M, Casian A, Flossmann O, et al. Long-term follow-up of patients with severe ANCA-associated vasculitis comparing plasma exchange to intravenous methylprednisolone treatment is unclear. Kidney Int 2013; 84: 397-402.

22. Walsh M, Merkel PA, Peh CA, et al. Plasma exchange and glucocorticoid dosing in the treatment of anti-neutrophil cytoplasm antibody associated vasculitis (PEXIVAS): protocol for a randomized controlled trial. Trials 2013; 14: 73.

23. Stone JH, Merkel PA, Spiera R, et al. Rituximab versus cyclophosphamide for ANCA-associated vasculitis. N Engl J Med 2010; 363: 221-232.

24. Jones RB, Tervaert JW, Hauser T et al. Rituximab versus cyclophosphamide in ANCA-associated renal vasculitis. N Engl J Med 2010; 363: 211-220.

25. Guillevin L, Pagnoux C, Karras A, et al. Rituximab versus azathioprine for maintenance in ANCA-associated vasculitis. N Engl J Med 2014; 371: 1771-1780.

26. Terrier B, Pagnoux C, Perrodeau É et al. Long-term efficacy of remission-maintenance regimens for ANCA-associated vasculitides. Ann Rheum Dis 2018; 77: 1150-1156.

27. Geetha D, Hruskova Z, Segelmark M, et al. Rituximab for treatment of severe renal disease in ANCA associated vasculitis. J Nephrol 2015; 41: 296-301.

28. Pepper RJ, McAdoo SP, Moran SM, et al. A novel glucocorticoid-free maintenance regimen for anti-neutrophil cytoplasm antibody-associated vasculitis. Rheumatology (Oxford) 2019; 58: 260-268

29. McAdoo SP, Medjeral-Thomas N, Gopaluni S, et al. Long-term follow-up of a combined rituximab and cyclophosphamide regimen in renal anti-neutrophil cytoplasm antibody-associated vasculitis. Nephrol Dial Transplant 2019; 34: 63-73.

30. Hellmark T, Segelmark M. Diagnosis and classification of Goodpasture's disease (anti-GBM). J Autoimmun 2014; 48-49: 108-112.

31. MCAdoo SP, Tanna A, Hrušková Z, et al. Patients double-seropositive for ANCA and anti-GBM antibodies have varied renal survival, frequency of relapse, and outcomes compared to single-seropositive patients. Kidney Int 2017; 92: 693-702. 